\title{
Seafood Ecolabels: For Whom and to What Purpose?
}

\begin{abstract}
Eco-labelling is regarded as an important tool as a means of promoting sustainable fisheries around the world as they provide consumers with the opportunity to exercise a choice between different seafood products and producers, and encourage the purchase of ecologically sustainable products. Consumers are generally considered to be the main drivers behind eco-labels as they are the end buyers of the products; however, there is very little existing peer reviewed data supporting this idea. This paper seeks to address the question of who is responsible for the market drive of seafood eco-labels. Through the examination of issues surrounding seafood eco-labels, this paper argues that the initiation and proliferation of eco-labels was a result of the interaction between non-government organizations, producers, purchasers and retailers, as the labels act as a useful insurance policy and marketing tool.
\end{abstract}

\footnotetext{
About the Author(s): Kaitlan Lay is a recent graduate from the Masters of Resource and Environmental Management program at Dalhousie University. During the program she focused most of her studies on fisheries management.
} 


\section{Introduction}

After centuries of overexploitation, global fish stocks have been subject to widespread decline and in some cases collapse (Myers \& Worm, 2003). As stated in the latest report by the Food and Agriculture Organization of the United Nations (FAO) (2010) about half (53\%) of global fish stocks are fully exploited, while approximately $28 \%$ are overexploited, $3 \%$ depleted, and $1 \%$ recovering from depletion (FAO, 2010). This overexploitation in combination with land-based sources of stress has led to drastically altered ecosystems and has sparked concern regarding the methods and the amount of fishing taking place in the marine environment. Increased efforts to restore marine ecosystems and rebuild fisheries have occurred through a variety of methods including the development of marine governance and management plans as well as through a number of social marketing campaigns, ranging from boycotts to eco-labelling (Myers \& Worm, 2003; Jacquet \& Pauly, 2007). In many cases these social campaigns aim to bring awareness of the current state of fisheries to consumers in hopes of inducing change.

The introduction of eco-labels was seen by many academics, non-profit organizations and industry members, as an opportunity to involve stakeholders in fisheries management by enabling consumers to exercise a choice between different seafood producers and products, and consequently affecting the economic decisions of those involved in commercial fishing (Beddington, 2008). In theory, seafood eco-labels are used to create a market-based incentive, encouraging the purchase of ecologically sustainable products, and ultimately creating better management practices of fisheries and aquaculture (Jacquet \& Pauly, 2007). In some instances eco-labels have initiated change in the fishing industry. Some of these changes have been brought about in light of corporate social responsibility (CSR) driving for environmental reforms, while other changes have been implemented by industry with the expectation of increased sales through product differentiation. Although eco-labelling continues to attract growing interest as a means of promoting sustainable fisheries around the world (Wessels, Donath \& Johnston, 1999), questions remain regarding their effectiveness in terms of the promotion and increased sustainability of the resource. Consumers are generally considered to be the driving force behind eco-labels as they are the end-buyer of the product. However, it has been stated that "the claim that eco-labels might guide consumers to more environmentally sound purchases is untenable" (Morris, 1997, p. 35) and to date there has been very little peer-reviewed economic research on market data determining the actual consumer demand of eco-labels.

Due to the lack of substantive data, it is unreasonable to state that consumer demand is necessary for producers to supply these eco-labelled products. This statement however, raises an important question: who is responsible for the market drive behind eco-labels? This paper argues that the main drivers behind eco-labelling and certification schemes are a variety of stakeholders other than consumers, including producers, non-governmental organizations (NGOs), purchasers and retailers, as the labels act as a useful insurance policy and marketing 
tool. The paper is organized as follows. The next section provides a brief background on ecolabels including the various types of eco-labels and some costs and benefits. The next section is devoted to explaining some of the issues that have arisen surrounding eco-labels. The following section contains information regarding the creation of a demand for eco-labels, while the section after that contains an analysis of the supply of eco-labelled goods and the players involved. The paper ends with some final comments in the concluding section.

\section{Eco-labels}

A seafood eco-label is a mark, logo, label or product endorsement affixed to a seafood product at the point of sale that implies to a purchaser that the product has been produced through ecologically sustainable procedures, and is from a source that is well managed (Ward \& Phillips, 2008a). Table 1 provides examples of some of the world's certification and ecolabelling programs that encompass seafood to one extent or another. In general, these labels are designed to "convey to the consumer otherwise unobservable information concerning a product's environmental impact" (Johnston, Wessels, Donath \& Asche, 2001, p.1). Eco-labels were developed in order to provide consumers with the option of purchasing sustainably produced products in the marketplace and are also seen as "a means of providing incentives to the fishing community, governments, international agencies and local authorities to improve the aspects of fisheries management for which they are responsible" (Gardiner \& Viswanathan, 2004). Under the FAO, eco-label schemes are defined as "entitl[ing] a fishery product to bear a distinctive logo or statement which certifies that the fish has been harvested in compliance with conservation and sustainability standards. The logo or statement is intended to make provision for informed decisions of purchasers whose choice can be relied upon to promote and stimulate the sustainable use of fishery resources" (2010, p.5). In the beginning, eco-labels were introduced by governments to compare and promote environmentally sound products within the same category (Gulbrandsen, 2006). Some examples of these early eco-labels include: The Blue Angel (1977), the Canadian Environmental Choice (1988), the Nordic Swan (1989), and the European Flower (1992). As stated by Gulbrandsen (2006), "[a]lthough some schemes were quite successful in terms of industry participation... many of the governmentsponsored programs suffered from low take-up by producers and retailers and little interest among consumers" (p. 477). This low up-take of government-sponsored programs led to a proliferation of market-based incentive systems. It is important to note that there is no overall global governance system in place to manage eco-label systems or to provide frameworks which could lead to uniformity of structure, function and accountability. All that exists are several umbrella systems that have been designed to set wide parameters for a range of ecolabelled products and services in general (Ward \& Philips, 2008a).

Introduction

After centuries of overexploitation, global fish stocks have been subject to widespread decline and in some cases collapse (Myers \& Worm, 2003). As stated in the latest report by the Food 
and Agriculture Organization of the United Nations (FAO) (2010) about half (53\%) of global fish stocks are fully exploited, while approximately $28 \%$ are overexploited, $3 \%$ depleted, and $1 \%$ recovering from depletion (FAO, 2010). This overexploitation in combination with land-based sources of stress has led to drastically altered ecosystems and has sparked concern regarding the methods and the amount of fishing taking place in the marine environment. Increased efforts to restore marine ecosystems and rebuild fisheries have occurred through a variety of methods including the development of marine governance and management plans as well as through a number of social marketing campaigns, ranging from boycotts to eco-labelling (Myers \& Worm, 2003; Jacquet \& Pauly, 2007). In many cases these social campaigns aim to bring awareness of the current state of fisheries to consumers in hopes of inducing change.

The introduction of eco-labels was seen by many academics, non-profit organizations and industry members, as an opportunity to involve stakeholders in fisheries management by enabling consumers to exercise a choice between different seafood producers and products, and consequently affecting the economic decisions of those involved in commercial fishing (Beddington, 2008). In theory, seafood eco-labels are used to create a market-based incentive, encouraging the purchase of ecologically sustainable products, and ultimately creating better management practices of fisheries and aquaculture (Jacquet \& Pauly, 2007). In some instances eco-labels have initiated change in the fishing industry. Some of these changes have been brought about in light of corporate social responsibility (CSR) driving for environmental reforms, while other changes have been implemented by industry with the expectation of increased sales through product differentiation. Although eco-labelling continues to attract growing interest as a means of promoting sustainable fisheries around the world (Wessels, Donath \& Johnston, 1999), questions remain regarding their effectiveness in terms of the promotion and increased sustainability of the resource. Consumers are generally considered to be the driving force behind eco-labels as they are the end-buyer of the product. However, it has been stated that "the claim that eco-labels might guide consumers to more environmentally sound purchases is untenable" (Morris, 1997, p. 35) and to date there has been very little peer-reviewed economic research on market data determining the actual consumer demand of eco-labels.

Due to the lack of substantive data, it is unreasonable to state that consumer demand is necessary for producers to supply these eco-labelled products. This statement however, raises an important question: who is responsible for the market drive behind eco-labels? This paper argues that the main drivers behind eco-labelling and certification schemes are a variety of stakeholders other than consumers, including producers, non-governmental organizations (NGOs), purchasers and retailers, as the labels act as a useful insurance policy and marketing tool. The paper is organized as follows. The next section provides a brief background on ecolabels including the various types of eco-labels and some costs and benefits. The next section is devoted to explaining some of the issues that have arisen surrounding eco-labels. The following section contains information regarding the creation of a demand for eco-labels, while 
the section after that contains an analysis of the supply of eco-labelled goods and the players involved. The paper ends with some final comments in the concluding section.

\begin{tabular}{|c|c|c|c|}
\hline Name & Geographic Area & Species & Logo \\
\hline $\begin{array}{l}\text { Marine Stewardship } \\
\text { Council }\end{array}$ & Worldwide & All & \\
\hline $\begin{array}{l}\text { Earth Island Institute } \\
\text { (EII) }\end{array}$ & Pacific Ocean & Tuna & \\
\hline Ecofish & Worldwide & $\begin{array}{l}\text { Crabs, spiny lobster, } \\
\text { halibut, mussels, } \\
\text { yellowfin tuna }\end{array}$ & \\
\hline Ocean Wise & Canada & All & \\
\hline Nuturland & Worldwide & $\begin{array}{l}\text { Salmonoids, } \\
\text { arapaima, milkfish, } \\
\text { mussels, penarid } \\
\text { shrimp }\end{array}$ & \\
\hline Friends of the Sea & Worldwide & All & \\
\hline
\end{tabular}

Table1. Examples of the world's certification and eco-labelling programs that include seafood.

\section{Types of Eco-labels}

There are two main types of eco-labelling schemes: mandatory and voluntary. Mandatory ecolabels are labels that are prescribed by law and appear frequently in regards to specific performance issues, such as fuel efficiency ratings required on cars in the U.S. (Horne, 2009; Wessels, et al. 1999). Eco-labels that are applied to seafood products, on the other hand, are voluntary. The International Standards Organization (ISO) uses three categories for voluntary labeling: Type I, II and III. The ISO classification system provides a uniform framework where a 
systematic structure of labelling is developed and implemented within an industry sector (Ward \& Phillips, 2008a). Type I labels are third-party certified product environmental label schemes that award the use of a logo that is associated with certified products. These eco-labels are created by organizations that are external to the relevant industry sector and are generally considered to be the most vigorous form of eco-labelling due to their distance from commercial influences (Ward \& Philips, 1999). Type II labels are based on the self-declared environmental claims made by manufacturers, importers, distributors or retailers. These types of labels can lead to consumer confusion in terms of the lack of common definitions (for example different organizations use the term "sustainably harvested" in reference to a variety of fishing methods and practices), the context in which the product is produced, used or disposed, as well as consumers having difficulties verifying the self-declared environmental claims (Wessels, et al., 1999). The number of exiting Type II labels is unknown, but undoubtedly outnumbers third party labeling schemes (Pedersen \& Neergaard, 2006). Finally, Type III labels provide quantitative life cycle environmental data about certain products. There also exists Type I-like labels which do not fall under ISO, which focus on a single product category rather than labeling a variety of product categories, an example of this type of label is the Forest Stewardship Certification scheme (Horne, 2009). Figure 1 represents the classification of product environmental labels by type as discussed above. Seafood eco-labels generally fall into the category of the ISO Type I label which, as previously mentioned, are administered through third party certification schemes. In order for a product to receive a label from a third party certifier, it must meet multiple criteria that are made publicly available and are uniformly applied (Wessels et al., 1999). According to Wessels et al., third party consumer product labelling serves three important functions in the marketplace: 1) it can provide independent evaluation and endorsement of a product; 2 ) it can act as a consumer protection tool; and 3) it can be a means of achieving specific environmental policy goals (p. 6). 


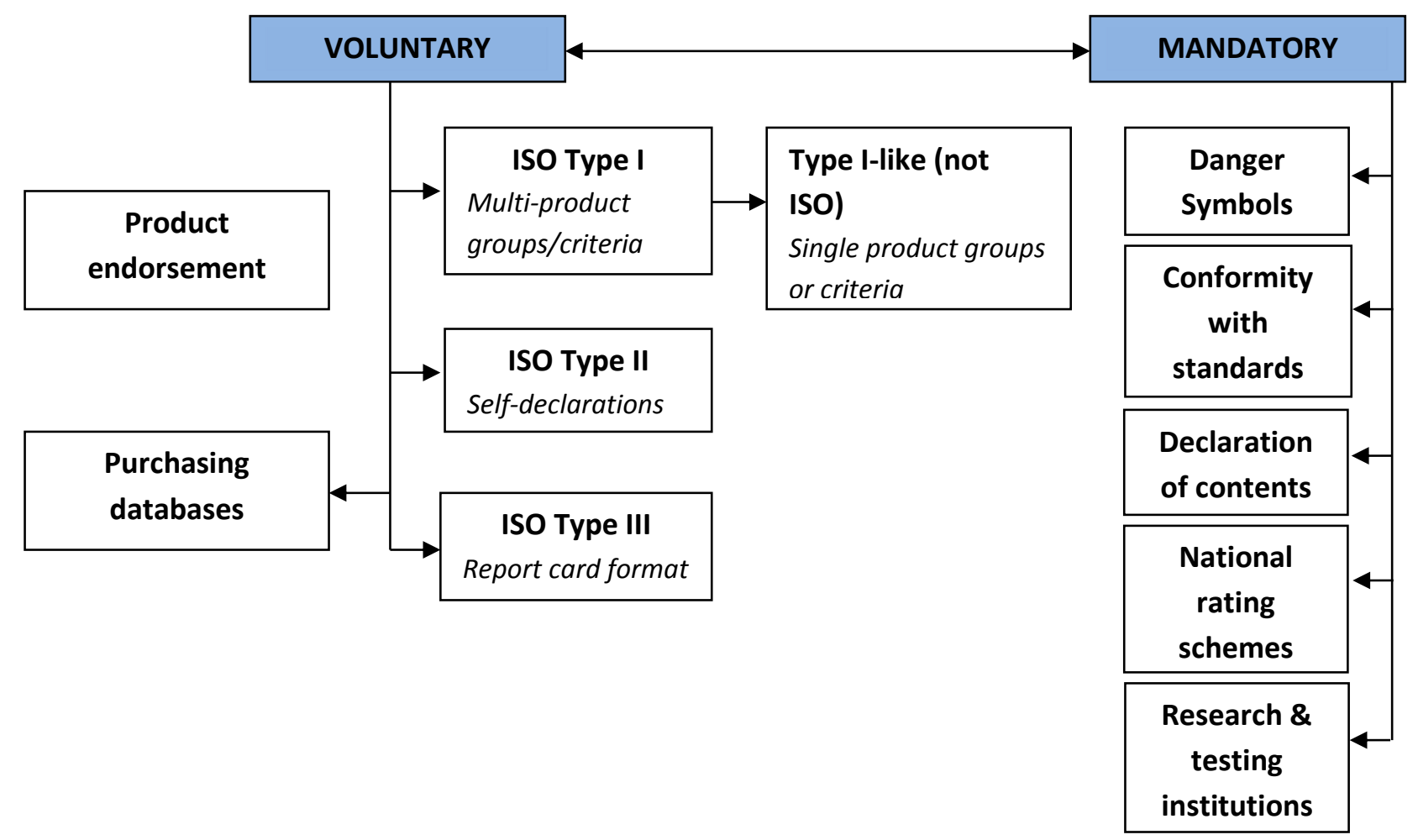

Figure 1. Classification of product environmental labels by type (adapted from Horne, 2009).

\section{Costs and Benefits of Eco-labelling}

Once a product has attained an eco-label it could be purchased at a higher price, providing the industry sectors involved in the eco-labelling program with a price advantage over unlabelled products. The increased purchase of eco-labelled products could create incentive for non- ecolabelled companies to alter their practices to fall in line with other sustainable producers in order to attain ecolabel status, which would reduce ecological impacts and improve the management of the resource. Along with these potential benefits that may be gained by the fishing industry from participating in an eco-labelling program, there are also a number of costs related to the programs that may inhibit some industry members from participating. Below is a table that lists some of the benefits and costs that are associated with co-labelling programs (Table 2). 
- Increased price, market share or market access, created by the market-pull for more sustainable products

- Increased industry standing for ecolabelled products and related products and industries

- Increased attractiveness for investment capital.

- Increased internal cohesion in the sector, responding to the common perception of benefits flowing from eco-labelling

- Potential for more value added products including through product differentiation

- Assembly and coordination of data and information specifically required for compliance assessment

- Initial certification and ongoing verification of compliance with the ecolabelling standard

- Protection against abuse of the labels to protect competing national or industry trade interests

- Organizing the industry into a cohesive group to be able to engage with the eco-labelling program and to effectively maintain the compliance conditions

- The costs of establishing a secure chain of custody for the product from the producer to the consumer

- The costs of advertising and awareness campaigns to specifically capitalize on the consumer appeal of the eco-label

Table 2. Potential Benefits and Costs to the Fishing Industry associated with eco-label programs. (Information compiled from Ward and Phillips, 2008a; Washington, 2008).

The costs and benefits related to eco-labelling within the fishing industry will vary depending on the scheme. The following section will briefly discuss some of the costs and benefits and development issues related to the leading global fisheries eco-labelling scheme, the Marine Stewardship Council.

\section{Marine Stewardship Council}

The most prominent fisheries eco-label that exists today is that of the Marine Stewardship Council (MSC). The MSC was developed in 1996 through a partnership between the World Wildlife Fund (WWF) and Unilever, which at that time was one of the world's largest buyers of frozen fish. The MSC was developed as an independent, non-profit, non-governmental organization with the intended goal of working for suitable marine fisheries through the promotion of responsible, environmentally appropriate, socially beneficial, and economically viable fishing practices (Kuntzsch, 1993). The MSC certification program is voluntary and is open to all fisheries, which are assessed by independent, third-party certification bodies against the MSC's extensive environmental standards for sustainable fishing which are briefly discussed in Table 3 below (Howes, 2008). 


\begin{tabular}{|l|l|}
\hline \multicolumn{2}{|c|}{ MSC Environmental Standard for Sustainable Fishing } \\
\hline Principle 1 & $\begin{array}{l}\text { A fishery must be conducted in a manner that does not lead to over- } \\
\text { fishing or depletion of the exploited populations and, for those } \\
\text { populations that are depleted, the fishery must be conducted in a } \\
\text { manner that demonstrably leads to their recovery. }\end{array}$ \\
\hline Principle 3 & $\begin{array}{l}\text { Fishing operations should allow for the maintenance of the structure, } \\
\text { productivity, function and diversity of the ecosystem (including habitat } \\
\text { and associated dependent and ecologically related species) on which } \\
\text { the fishery depends. }\end{array}$ \\
\hline $\begin{array}{l}\text { The fishery is subject to an effective management system that respects } \\
\text { local, national and international laws and standards and incorporates } \\
\text { institutional and operational frameworks that require use of the } \\
\text { resource to be responsible and sustainable. }\end{array}$ \\
\hline
\end{tabular}

Table 3. MSC Fishery Standard. Principles and Criteria for Sustainable Fishing. (Information compiled from the MSC environmental standard for sustainable fishing. Retrieved from, www.msc.org).

If the certifiers determine that the fishery meets the standards, they are awarded a certificate which is good for five years, subject to annual surveillance audits and possible on-site visits and inspections (Howes, 2008). There are currently 133 certified fisheries in the MSC program, which range from Aker Biomarine's Antarctic krill to Western Australian rock lobster (Marine Stewardship Council, 2011). Although the MSC has certified a number of fisheries sealing them with their stamp of approval, there has been skepticism surrounding the program since its beginnings. In 1999 in response to these criticisms, MSC separated itself from its two parents, Unilever and WWF and began to operate independently. However, even after the separation there continued to be skepticism regarding the organization and the methods that it uses. As stated by Ponte (2008) and May, Leadbitter, Sutton \& Webber (2003) many of the skeptics questioned the MSC initiative on the basis of:

- The motivations of Unilever in starting it;

- The centralized and corporate structure of MSC;

- A balance between public interest and timely progress;

- A bias in favor of industrial fisheries and developed country fisheries in particular;

- The lack of consultation with fishers in general and developing country representatives in particular;

- The perception in developing countries that eco-labels constitute technical barriers to trade;

- Regional concerns - different views about by-catch etc.;

- The financial and human resource costs that achieving certification would entail in developing countries and especially small-scale fisheries; and 
- The recognition that the current state of scientific knowledge is no guarantee of sustainability; and

- Definitional issues - aquaculture vs. wild catch.

MSC argued that their certification system was being field-tested in various settings, including small-scale fisheries and fisheries in the developing world (Ponte, 2008). When discussing MSC and eco-labels in general, it is important to keep in mind that "independent certification of fisheries has never been attempted before on a global scale and the task of building an evergrowing base of consensus on how to achieve real incentives for improved management is never ending" (May et al., 2003, p.31). Therefore, although MSC and other third party certified eco-labels may encounter some issues as they develop, they are important tools that have begun the discussion concerning the dire conditions which face some of our natural global resources.

\section{Issues surrounding Eco-labels}

According to Horne (2009), there are four themes that can be used to evaluate the strength of an eco-label: 1) coverage (range of environmental issues covered); 2) inclusion of stakeholder needs (participative democracy); 3 ) uptake, independence and acceptance (evidence of influence of the label); and 4) measured environmental/sustainable consumption outcomes (demonstrating conservation of natural capital and intergenerational equity) (p.176). However, even on the chance that an eco-label meets each of these four criteria there are a number of issues that continue to plague the implementation and success of eco-labels in fisheries. One of the main issues raised regarding eco-labels is that due to their voluntary nature some customers may be misled into believing that only eco-labelled products are produced in a sustainable manner, which is not always the case. There are a number of other issues regarding eco-labels in general, which include:

- The lack of objectivity in setting the criteria;

- The difficulty of setting product category boundaries since no two goods are perfect substitutes for one another and some of the products may have many different uses (Bleach, for example, can be used to clean clothes, toilets and floors);

- The arbitrariness of the process of selecting and updating criteria, as it is not possible to estimate accurately all the damage that the entire life cycle of the product can have on the environment;

- The lack of estimated demands for labeled goods;

- The lack of real rewards for environmental improvements (the awards are restricted in most cases to the best products); and finally

- The shortness of the validity period of the label before its revision, especially problematic for capital intensive industries. (Gallastegui, 2002, p. 318). 
The above mentioned issues are only some examples of problems that an eco-label program may encounter, however, each eco-label may face different challenges as the schemes vary considerably, covering a variety of topics such as by-catch issues, fishing methods and gear, sustainability of stocks, conservation of eco-systems, and even social and economic development (Washington, 2008). The number of eco-labels is expected to continue to grow, therefore it is important to identify the existing issues with eco-labels in order to distinguish where, if possible, changes can be made to allow for eco-labels to be implemented successfully.

\section{Creating demand for eco-labels}

As Gulbrandsen states (2006), "when there is no demand for a particular brand, businesses try to create one by building a brand" ( $p .482$ ). The development of a demand for eco-labels in fisheries was necessary, which required the promotion of the programs to major retailers, incentives from environmental groups, as well as campaigning in order to enhance consumer awareness. Eco-labelled products are not necessarily globally marketable and as Washington states (2008), the most conducive markets are those where there is a:

Relatively environmentally aware population and active civil society and media; where fish and seafood are typically sold in supermarkets where consumption patterns are based on a traditionally limited range of fish products and where there is a tradition of purchasing processed/packaged dish and seafood that lend themselves to the attachment of a label of point of sale. (p. 2)

It has been noted that although MSC has certified 133 fisheries, only two are located in Asia, which is the world's largest seafood market (Gulbrandsen, 2006; MSC, 2011). "Considering China is the world's leading fish exporting country and that almost $40 \%$ of world fishery production was traded internationally by 2001 , increasing participation from developing countries is crucial to help resolve the global fishery management challenges" (Gulbrandsen, 2002 , p. 485). Altering consumer behavior not only in Asia, but around the world is an important step in creating more sustainable fisheries.

The existing global environmental issues can be linked to the consumption of goods and it is therefore important to look at the sustainability of present consumer behavior (Gallastegui, 2002). The idea of the "green consumer" has proliferated in recent years, causing firms to allocate substantial resources in order to satisfy the needs of this new market segment (Pedersen \& Neergaard, 2006). "Green consumerism" is defined as "the purchasing and nonpurchasing decisions made by consumers, based at least partly on environmental or social criteria" (Peattie, 1995). The characteristics that determine a "green consumer," however, remain unclear and are complicated by the fact that environmental consciousness does not always directly affect purchasing behavior (Gallastegui, 2002). The assumption, therefore, 
cannot be made that someone who is concerned about the environment will be a "green consumer." Pedersen \& Neergaard (2006) describe some inconsistencies, which limit the explanatory power of the "green consumer" stereotype. These inconsistencies include the fact there are different kinds of "green" consumers, who may not share the same values, attitudes and behavioral patterns:

- Some consumers are only "green" when it comes to certain products and general environmental awareness does not necessarily lead to a specific behaviour; budget constraints may make it difficult for some consumers to consistently purchase "green" products;

- Some consumers may be well educated and have a preference regarding some "green" labels and not others;

- Some consumers are only "green" because it is trendy and will forget about labelling when other issues catch their attention;

- Some consumers are "green" without knowing it. These consumers purchase products without recognizing the labels, which blurs the identification of the "green" consumer segment;

- Due to vague or misleading advertising, "green" consumers may be manipulated into buying products that are not "green";

- "Green" consumers are only green when they trust the manufacturer and/or the label; and "green" consumers are only green because the environmentally friendly products are bought on a routine basis. When buying a product becomes a routine, the consumer does not perform a continuous search for alternatives (p.21).

These inconsistencies demonstrate that an attempt to place the "green consumer" in a box underestimates the complexity of actual consumer behaviour (Pedersen \& Neergaard, 2006).

It is generally accepted that consumer demand for eco-labelled products has been quite low, as has the readiness to pay a price premium for the product (Ward \& Phillips, 2008; Roheim, 2008; Bostrom \& Klintman, 2008; Gulbrandsen, 2006). Consumers do not initiate the demand for eco-labelled seafood and therefore the role of marketing and creating a market for sustainable seafood is very important (Roheim, 2008). In relation to fisheries "consumers seem unaware of the linkage between eco-labelled seafood and the ecological conditions of the oceans and fish stocks, or, perhaps even worse, at this stage not many seem to care" (Ward \& Phillips, 2008).

\section{The supply of Eco-labelled Goods: Opportunities and Challenges for Stakeholders}

Eco-labels are market-based incentives which present the possibility of directing industry practices towards more sustainable activities (Ward, 2008). Within the market, various players 
have and continue to be involved in the promotion of sustainable use of the fishery resource. The interactions between industry, social movement organizations, government, and consumers spurred the rise of certification markets and the application of eco-labels. Over the past decades environmental groups have gained strength through their expansion from limited domestic arenas to transnational action and with this expansion has come power in numbers and the ability to make changes in the management of resources. "The rise of global norms and principles related to corporate social responsibility and sustainable development, frequently invoked by environmental groups, meant that retailers committed to sustainability could not afford to ignore the calls for demonstrating responsible procurement policies" (Gulbrandsen, 2006, p. 486). This increased pressure from environmental groups has led to the initiation and application of voluntary governance systems, such as eco-labels, as well as the increasing use of NGOs in policy making and implementation (Gulbrandsen, 2006). Although environmental movements have pushed for the widespread use of voluntary governance systems with some industry members accepting the push and government approving of some schemes, it is important to remember that industry, government and NGOs have different motives when it comes to eco-labels, which are shadowed under the shared common goal of sustainable use of the resource. The development of MSC is a good example of where an NGO and industry had different objectives, but managed to work together in order to meet a shared goal. Although the two organizations involved were aiming to reduce the increasingly serious trend of unsustainable fishing, their motives were very different. WWF was concerned with the widespread impact of overfishing on marine ecosystems and the limited capacity of regulatory programs to ensure that fisheries are sustainable. Unilever argued that the future of some of its brand name companies that dealt in frozen seafood, such as Birdseye and Iglo, were threatened by growing consumer perception about the oceans and potential future interruptions of supply caused by overfishing (May et al., 2003, p.17). The differing motives which drive industry, purchasers, retailers, government, NGOs and consumers will be explored in the following sections.

\section{Industry}

Companies create institutional arrangements in order to find solutions to collective-action problems and to allow markets to function smoothly (Gulbrandsen, 2006). The adoption of voluntary standards, such as eco-labels, is an example of such institutional arrangements. There are a variety of reasons why industry members may choose to adopt voluntary standards. Some believe that it stems from the desire for price premiums, access to new markets, consolidation or expansion of market share in existing markets, potential for more value-added products including through product differentiation, longer-term advantages from the improved management of fisheries resources (future production), to protect their reputation, to provide credible information to consumers, or that it is linked to the anticipation of stronger public policy regulations or to prevent enactment of more demand regulations (Washington 2008; Gulbrandsen, 2006). It may also be related to peer pressure from within the 
industry itself, as environmental and social reputations reflect in many cases on the industry as a whole, not just on individual firms (Gulbrandsen, 2006). Eco-labelling is closely linked to corporate social responsibility, which has taken the forefront in today's marketplace, where companies attempt to prove their level of "environmentally friendliness." Corporate social responsibility (CSR) is defined as the way companies integrate social, environmental, and economic concerns into their values and operations in a transparent and accountable manner (Foreign Affairs and International Trade Canada, 2011). Firms that pursue CSR do so because it is profitable through improving demand conditions, improving the public image of firms, and improving factor-supply conditions (Roheim, 2008). "Labeling stimulates a green image of progressive companies; they become a credible way to express greenness and corporate responsibility. There is also an implicit assumption that the involvement of such external stakeholders automatically guarantees good standards. Labeling can also help companies by preventing or dealing with negative publicity and reputational risk prevention" (Bostrom \& Klintman, 2008, p.70).

\section{Producers}

\begin{tabular}{|c|c|}
\hline Country & Information \\
\hline United Kingdom & $\begin{array}{l}33 \% \text { of the surveyed public willing to pay an average of } 13 \% \text { premium for sustainable produced } \\
\text { timber }\end{array}$ \\
\hline United Kingdom & $\begin{array}{l}25-50 \% \text { of the Britons ready to pay up to } 25 \% \text { premium for (credible) goods with improved } \\
\text { environmental performance }\end{array}$ \\
\hline United Kingdom & $\begin{array}{l}\text { Of consumers surveyed [...] premiums suggested (for ethical products) ranged between } 10 \text { and } \\
18 \text { pence }\end{array}$ \\
\hline United Kingdom & Caf'edirect has a price premium of 5-10\% over commercial premium brands of coffee \\
\hline United Kingdom & Consumers willing to pay a $13 \%$ price premium for tropical timber products \\
\hline Europe & Consumers willing to pay a $5-15 \%$ premium for sustainable timber products \\
\hline Europe & $\begin{array}{l}37 \% \text { of consumers said they would be prepared to pay a premium of } 10 \% \text { for } \\
\text { bananas of equivalent quality produced according to fair trade standards }\end{array}$ \\
\hline Canada & $64 \%$ of respondents willing to pay a $10 \%$ premium for a product bearing the Ecologo \\
\hline Singapore & $5 \%$ premium for the Singapore Green label \\
\hline United States & $34 \%$ of consumers surveyed willing to pay a $6-10 \%$ price premium for sustainable wood \\
\hline United States & $75 \%$ of consumers surveyed willing to pay a $1-5 \%$ price premium for sustainable wood \\
\hline United States & $57 \%$ of the surveyed public willing to pay a $1-5 \%$ price premium for sustainable wood \\
\hline
\end{tabular}




\begin{tabular}{|l|l|}
\hline United States & $82 \%$ of consumers ready to pay 5\% premium for 'greener' products. \\
\hline United States & Willingness to pay for environmental/health attributes on food between 5 and $7 \%$ \\
\hline
\end{tabular}

Table 4. Price premiums for eco-labels. Information retrieved from Gallastegui, 2002.

As Washington states (2008), "there has been little in-depth analysis and therefore little empirical evidence of the costs and benefits experienced by producers operating in fisheries that have gained MSC or other forms of eco-certification," which includes the argument surrounding price premiums (p. 2). Price premiums are defined as "the increase in the price above minimum average cost of high quality" (Gallastegui, 2002). Table 4 contains some estimates of price premiums for labelled goods. Companies involved with eco-labels do not always experience resource savings, and consumers do not automatically reward companies with environmental friendly policies (Pedersen, 2006, p.27). Certification schemes are also expensive, with producers assuming the bulk of the costs, which include the actual costs of certification (expert fees), compliance costs related to adjusted management practices, data collection and record keeping, and costs related to potential adjustments in fisheries management (catch limits) (Washington, 2008). In terms of fisheries, the cost of MSC preassessment can range from an estimated US\$10,000 for a simple small fishery to over US $\$ 250,000$ for a large or complex fishery (Washington, 2008). Aside from the high cost of certification, there are also a number of other concerns that have been put forth by producers which include transparency and participation, legitimacy, applicability, impacts on trade, fears that schemes that are initially voluntary will eventually become mandatory, and governance (Washington, 2008, p. 27).

Table 4. Price premiums for eco-labels. Information retrieved from Gallastegui, 2002.

\section{Retailers}

Retailers have seen the potential of eco-labels as a marketing tool and as a way of tapping into growing consumer demand for ethical products and as insurance against boycotts and bad press from environmental groups and in the media (Washington, 2008). The costs related to eco-labels for retailers is relatively low, while the benefits are high and include reputation enhancement, adding value to private brands, and returns related to better risk management (Washington, 2008). Eco-labels for retailers play an important role in positioning a company as a responsible buyer with NGOs and the media, and does not have so much to do with the supply of eco-labelled products to consumers (Washington, 2008). Retailers are now seen as the key players in the proliferation of eco-labels, as they are the decision makers regarding stocking and promoting eco-labelled products. The increasing support of eco-labels from retailers has become obvious in the past decade with numerous chains, such as Tesco and Marks and Spencer incorporating sustainability seafood procurement policies into their marketing plans. The biggest food retailer in the U.S., Wal-Mart, announced in 2006 that it was 
going to adopt a new corporate policy on sustainable seafood. The company stated that within 3-5 years it planned to deal only in MSC certified seafood (Sutton \& Wimpee, 2008). The promotion of eco-labelled products from retailers also creates competition between the chains, and allows those who have pledged to supply eco-labelled products to market their brand as sustainable, improving their reputation among consumers. In terms of seafood eco-labels, the chain of custody audits that occur within MSC frees the supermarket of having do it themselves, which is therefore cost effective and ensures traceability from boat to point of sale (Washington, 2008).

\section{Government}

Government's role in non-state eco-labelling systems vary depending on the scheme. With the Forest Stewardship Council (FSC) for example, government participation is explicitly forbidden, whereas with MSC, governments are treated like all other stakeholders and offered no preferred position (Gulbrandsen, 2006). Due to this lack of involvement in the development of the MSC some governments became skeptical of the scheme and cooperated with the FAO's Committee of Fisheries in order to develop guidelines for fish and fishery product ecolabelling, which were adopted in March 2005. The guidelines set out principles, minimum requirements, and procedural aspects which should be encompassed by all eco-labelling schemes and provided a benchmark against which various schemes can be compared (Washington, 2008). The development of these guidelines was seen by some as an attempt from governments to regain control over an area of importance within the fisheries sector, as concerns were raised by governments regarding private outside interests evaluating the effectiveness of national fisheries management regimes (Gulbrandsen, 2006; Washington, 2008). As Gulbrandsen states (2006), "fishery certification and labeling are going through a period of institutionalization, and states are not prepared to let non-state bodies define fishery labeling rules and procedures on their own" (p. 482).

Although there were some concerns raised by governments regarding the implementation of MSC, in countries that already employed effective fisheries management regimes MSC was regarded with neither positive or negative reactions. It is believed that these governments concluded that if the implementation of eco-labels improved industry and increased export, then it could only be regarded as a good thing (Washington, 2008). The opportunity exists for government to become involved with non-state eco-labelling schemes through the offer of moral support, which in turn may enhance the standing of the label. As Gulbrandsen states (2006), "by approving specific labeling schemes, through public procurement or other policies, governments signal that those schemes are legitimate and credible governance systems that corporate procurers and other buyers also can rely on" (p. 479). There is also the possibility that in some cases certification schemes may assist government conservation policies though incentivizing industry to adopt more environmentally friendly fishing practices (Washington, 2008). 


\section{NGOs}

In the past decades there has been mass expansion of activity from transnational activists and NGO networks, with current activists having the ability to organize across national boundaries, allowing them to bring large numbers of stakeholders together in various countries in order to pressure industry and government (Coddington, 1993; Gulbrandsen, 2006). As Gulbrandsen states (2006), "social movement organizations facilitate political consumerism by praising or damning industry practices, mobilizing consumers and advising companies about how they can tap into potential consumer demand" (p.479). In the early 1990s NGOs began to turn their attention from land based issues to the oceans and began to realize the gross mismanagement by government that had been taking place in the ocean environment and fisheries (Sutton \& Wimpee, 2008). As NGO involvement and study began to spread through ocean conservation, it became apparent that the industry's influence over certain national government's domestic and international fishery management was creating serious management issues which led the conservation community to turn to the market in order to make changes (Sutton \& Wimpee, 2008). As NGOs started working with industry players it became apparent that "the ecological fate of the world is in the hands of industry" (Coddington, 1993). With this shift of focus from government to industry the conservation community began to realize that their typical tools of lobbying, campaigning, and litigation were useful but were only capable of producing slow change as they were geared to fighting industry and government. In order to gain results in a more timely manner, NGOs began to enter into partnerships with industry to effect change in resource management (Phillips, Chaffee, Ward \& Sutton, 1993).

NGOs involved in fisheries are interested in ensuring the sustainable use of the resource, protection of biodiversity, and in some cases in the promotion of equity in the allocation of resources so that livelihoods are protected and the living conditions of fishing communities are improved (Leadbitter, 2008). As Roheim and Sutinen state (2006), "civil society groups have played a significant role in promoting sustainable seafood products, primarily by raising public awareness of the issue and continually placing it on the agenda of governments and regional fisheries management organizations" (p.15). These groups have attempted to influence the purchasing habits of consumers through education regarding sustainable fisheries and aquaculture products. NGOs have tapped into the concerns that were brought forward by "green consumers" and have used these concerns to wield influence over consumers purchasing decision or the procurement policies of large firms (Washington, 2008). In terms of fisheries, NGOs have used eco-labels as an attempt to reward members involved in the fishing industry who practice responsible fishing through the encouragement of consumer purchases as well as placing pressure on large retailers to stock the eco-labelled products (Washington, 2008). 


\section{Consumer Role}

Over the past few decades consumers have begun to adopt positive views towards environmental issues and in some cases have shown a willingness to incorporate environmental information in their consumption decision (Pedersen \& Neergaard, 2006). The purpose of eco-labels, from the consumer's point of view, is to reduce uncertainty surrounding the environmental performance of a product and enable the consumer to choose a product that will cause less environmental damage. However, as previously mentioned in "Issues Surrounding Eco-Labels" (above), uncertainty still remains around the issue of consumers stating their intentions of being a "green consumer" and their actual purchasing behavior and attitudes towards green products. This unpredictability relating to purchasing behavior is linked to the influence on the consumer by individual limitations as well as the social context of which they are a part (Coddington, 1993). As Pedersen and Neergaard state (2006):

Economic constraints, bounded rationality and attention mosaics affect the consistency of green consumerism. Moreover, consumers' attitudes and behaviour affect and in turn are affected by the dominant economic, social, cultural and political institutions in society. Consumers are not born with a fixed set of preferences, and the ongoing interrelation between individuals and institutions shapes the value and belief system as well as the actual behaviour. Because it is difficult to identify a stable group of consistently green consumers, the market impact of environmentally labelled products and services becomes less predictable. (p. 25)

Directly associated with consumer purchases of eco-labelled products are the issues of information overload and confusion. In general, consumer knowledge of the context of environmental labels is very limited, which presents the important fact that eco-labels should not be regarded as objective or as functional information (Pedersen \& Neergaard, 2006). In many cases, consumer confusion related to eco-labels is caused by the proliferation of voluntary eco-labels and uncertainty between third-party certified and self-declared labels (Horne, 2009). A survey from 2001 concluded that more than $50 \%$ of consumers agreed that it was impossible for ordinary people to understand the meaning and content of the different labeling schemes and between 86.4 and $97.3 \%$ found that there were too many labeling schemes (MAPP, 2001 as cited in Pedersen \& Neergaard, 2006).

Although today's consumer is considered to be much more environmentally aware than the typical consumer from a few decades ago, the uncertainty surrounding eco-labels has made it difficult for consumers to gain clarity about the different schemes, and therefore has limited the success of eco-labels in general. This has been evident as consumer demand for eco-labelled products remains quite low (Ward \& Phillips, 2008a). Alongside the uncertainty surrounding eco-labels, consumers also take other factors into consideration such as quality, values, 
identification, social pressure and habit (Horne, 2009). One of the most important factors playing a role in consumer acceptance of eco-labels is that of price. Some consumers may wish to avoid being part of the minority paying a price premium, while the majority continues to purchase cheap goods, with the consequences through increased environmental impacts affecting all (Horne, 2009).

\section{Conclusion}

Eco-labeling in fisheries is a fast growing market that is fuelled by the promise of marketing benefits, more sustainable fish stocks, and fewer environmental impacts (Ward, Phillips \& Chaffee, 1993). However, there is very little ecological evidence which supports the broad ecological effectiveness of seafood sustainability programs, with only a very small number of ecological successes documented for seafood eco-labelling (Ward, 2008). As this paper has explained, the development and proliferation of eco-labels did not stem from consumer demand, nor from producers, but instead was a result of the interaction between NGOs, company decisions and consumer concern. Industry participation in certification schemes was brought about as a response to the pressure from environmental groups. The application of eco-labels on products allowed producers to reassure NGOs, retailers, governments and consumers that they were committed to using the resources sustainably. Retailers and brand owners are the current drivers of eco-labels. They are motivated by the minimal costs that they incur (unlike the producers) and the reputation boost that they attain among NGOs, media and consumers as responsible buyers. For governments, some choose to use eco-labels to their advantage as it may decrease the necessity of implementing unpopular or costly command and control policies (Pedersen \& Neergaard, 2006). The above mentioned stakeholders all stand to gain something by increasing the use and implementation of eco-labels, whereas consumers have a different relationship with eco-labels. Although consumers may see ecolabels as a helpful tool that may result in environmental standards which exceed government regulations, the argument that consumers are the main drivers behind eco-labels remains unsupported. Due to the uncertainty that consumers may have regarding consumer productbased eco-labels (see "Consumer Role," above), there remains to be seen any significant environmental improvements through eco-labels. The possibility does however remain for ecolabels to become more informative and coherent, which would allow consumers to better understand the various programs and consequently their awareness and perception of environmental issues around fisheries. In order for this to take place more strict regulations would need to be set in place to allow for consumers to clearly understand the various categories of eco-labels. By making the programs easier to understand, eco-labels may then begin to play the role that they were originally assigned, which was to provide consumers with the opportunity to make informed choices when purchasing products. 


\section{References}

Beddington, J. (2008) Foreword. In Ward, T. \& Phillips, B. (Eds. Seafood ecolabelling: Principles and practices. Oxford, UK: Blackwell Publishing Ltd.

Bostrom, M. \& Klintman, M. (2008). Eco-standards, product labeling and green consumerism. Hampshire, UK: Palgrave MacMillan.

Coddington, W. (1993). Environmental Marketing, McGraw-Hill, New York, NY.

Food and Agriculture Organization of the United Nations [FAO]. (2010). The state of world fisheries and aquaculture. Retrieved from: http://www.fao.org/docrep/013/i1820e/i1820e00.htm

Foreign Affairs and International Trade Canada. (2011). Corporate social responsibility. Retrieved from: http://www.international.gc.ca/trade-agreements-accords-commerciaux/ds/ csr.aspx?view=d

Gallastegui, G. (2002). The use of eco-labels: A review of the literature. European Environment, 12, 316-331.

Gardiner, P. \& Viswanathan, K. (2004). Ecolabelling and fisheries management. Penang, Malaysia: WorldFish Center.

Gulbrandsen, L. (2006). Creating markets for eco-labelling: Are consumers insignificant? International Journal of Consumer Studies, 20, 477-489.

Horne,R. (2009). Limits to labels: The role of eco-labels in the assessment of product sustainability and routes to sustainable consumption. International Journal of Consumer Studies, 33, 175-182.

Howes, R. (2008). The Marine Stewardship Council Programme. In Ward, T. \& Phillips, B. (Eds). Seafood ecolabelling: Principles and practices. Oxford, UK: Blackwell Publishing Ltd. http://dx.doi.org/10.1002/9781444301380.ch4

Jacquet, J. \& Pauly, D. (2007). The rise of seafood awareness campaigns in an era of collapsing fisheries. Marine Policy, 31, 308-313.

Johnstron, R., Wessels, C., Donath, H. \& Asche, F. (2001). Measuring consumer preference for ecolabeled seafood: An international comparison. Journal of Agricultural and Resource Economics, 26(1), 20-39.

Kuntzsch, V. (2003). Is ecolabelling working? In Phillips, B., Ward, T. \& Chaffee, C. (Eds). Ecolabelling in fisheries, what is it all about? Oxford, UK: Blackwell Publishing Ltd. 
Leadbitter, D. (2008). Market-based mechanisms - Improving fisheries management? In Ward, T. \& Phillips, B. (Eds). Seafood ecolabelling: Principles and practices. Oxford, UK:

Blackwell Publishing Ltd.

http://dx.doi.org/10.1002/9781444301380.ch9

MAPP 2001. Den Forbrugerbaserede Værdi af en Mærkning: Med Fokus på Svanemærket, Working Paper 79. The Aarhus School of Business Centre for Research on Customer Relations in the Food Sector (MAPP). http://130.226.203.239/Pub/Mapp/wp/wp79.PDF

Marine Stewardship Council [MSC]. (2011). Marine Stewardship Council, Certified sustainable seafood. Retrieved from:

http://www.msc.org/

May, B., Leadbitter, D., Suttone, M. \& Webber, M. (2003). The Marine Stewardship Council (MSC), Background, rationale and challenges. In Phillips, B., Ward, T. \& Chaffee, C. (Eds). Eco-labelling in fisheries, what is it all about? Oxford, UK: Blackwell Publishing Ltd.

Morris, J. (1997). Green goods? Consumers, product labels and the environment. London, UK: Coronot Books.

Myers, R. \& Worm, B. (2003). Rapid worldwide depletion of predatory fish communities. Nature, 423 , p. $280-283$.

Peattie, K. (1995). Environmental Marketing Management: Meeting the Green Challenge. Michigan, USA: Pitman.

Pedersen, E. \& Neergaard, P. (2006). Caveat Emptor - Let the buyer beware! Environmental labeling and the limitations of 'Green' Consumerism. Business Strategy and the Environment, 15(1), 15-29

Phillips, B., Chaffee, C., Ward, T. \& Sutton, M. (2003). Introduction. In Phillips, B., Ward, T. \& Chaffee, C. (Eds). Eco-labelling in fisheries, what is it all about? Oxford, UK: Blackwell Publishing Ltd.

Ponte,S . (2008). The Marine Stewardship Council and Developing Countries. In Ward, T. \& Phillips, B. (Eds). Seafood ecolabelling: Principles and practices. Oxford, UK: Blackwell Publishing Ltd. http://dx.doi.org/10.1002/9781444301380.ch14

Roheim, C. \& Sutinen, J. (2006). Trade and marketplace measures to promote sustainable fishing practices. Geneva, Switzerland: International Trade and Sustainable Development Issue Paper No. 3. Geneva, Switzerland. 
Roheim, C. (2008). The Economics of Ecolabelling. In Ward, T. \& Phillips, B. (Eds). Seafood ecolabelling: Principles and practices. Oxford, UK: Blackwell Publishing Ltd.

Roheim, C., Asche, F. \& Santos, J. (2011). The elusive price premium for ecolabelled products: Evidence from seafood in the UK market. Journal of Agricultural Economics, 62(3), 655-668.

http://dx.doi.org/10.1002/9781444301380.ch2

Sutton, M. \& Wimpee, L. (2008). Towards sustainable seafood: The evolution of a conservation movement. In Ward, T. \& Phillips, B. (Eds). Seafood ecolabelling: Principles and practices. Oxford, UK: Blackwell Publishing Ltd. http://dx.doi.org/10.1002/9781444301380.ch20

Ward, T. \& Phillips, B. (2008a). Ecolabelling of seafood: the basic concepts. In Ward, T. \& Phillips, B. (Eds). Seafood ecolabelling: Principles and practices. Oxford, UK: Blackwell Publishing Ltd. http://dx.doi.org/10.1002/9781444301380.ch1

Ward, T. \& Phillips, B. (2008b). Anecdotes and lessons of a decade. In Ward, T. \& Phillips, B. (Eds). Seafood ecolabelling: Principles and practices. Oxford, UK: Blackwell Publishing Ltd. http://dx.doi.org/10.1002/9781444301380.ch21

Ward, T. (2008). Measuring the success of seafood ecolabelling. In Ward, T. \& Phillips, B. (Eds). Seafood ecolabelling: Principles and practices. Oxford, UK: Blackwell Publishing Ltd.

http://dx.doi.org/10.1002/9781444301380.ch10

Ward, T., Phillips, B. \& Chaffee, C. (1993). Conclusion. In Phillips, B., Ward, T. \& Chaffee, C. (Eds). Eco-labelling in fisheries, what is it all about? Oxford, UK: Blackwell Publishing Ltd.

Washington, S. (2008). Ecolabels and marine capture fisheries: Current practice and emerging issues. Retrieved from http://www.nmfs.noaa.gov/ocs/mafac/meetings/2008 07/docs/GLOBEFISH Ecolabels m arine capture fisheries.pdf

Wessells, Donath, \& Johnston. (1999). Consumer preferences for certified seafood, results of a consumer study. University of Rhode Island Department of Environmental and Natural Resource Economics. 